\title{
THE Pf332 GENE CODES FOR A MEGADALTON PROTEIN OF PLASMODIUM FALCIPARUM ASEXUAL BLOOD STAGES
}

\author{
DENISE MATTEI \& ARTUR SCHERF
}

Unité de Parasitologie Expérimentale, Institut Pasteur 25, Rue du Docteur Roux, 75724 Paris CEDEX 15, France

We characterized the Plasmodium falciparum antigen 332 (Ag332) which is specifically expressed during the asexual intraerythrocytic cycle of the parasite. The corresponding Pf332 gene has been located in the subtelomeric region of chromosome 11. Furthermore, it is present in all strains so far analyzed and shows marked restriction length fragment polymorphism. Partial sequence and restriction endonuclease digestion of cloned fragments revealed that the Pf332 gene is composed of highly degenerated repeats rich in glutamic acid. Mung been nuclease digestion and Northern blot analysis suggested that the Pf332 gene codes for a protein of about $700 \mathrm{kDa}$. These data were further confirmed by Western blot and immunoprecipitation of parasites extracts with an antiserum raised against a recombinant clone expressing part of the Ag332. Confocal immunofluorescence showed that Ag332 is translocated from the parasile to the surface of infected red blood cells within vesicle-like structures. In addition, Ag332 was detected on the surface of monkey erythrocytes infecled with Plasmodium falciparum.

Key words: malaria - polymorphism - chromosome location - confocal immunofluorescence

Plasmodium falciparum antigens exposed on the surface of parasitized red blood cells represent important targets of the host's immune response. Some of these molecules have been implicated in the cytoadherence of infected erythrocytes on the endothelial cells of the capillaries (reviewed by Berent et al., 1990), rosetting (Wahlgreen, 1986) and opsonization (Groux \& Gysin, 1990; Groux et al., 1990).

The immunological screening of a $P$. falciparum (Palo Alto strain) expression library allowed us to isolate a clone, here referred to as G332, which contains an insert of 303 base pairs, coding for degenerated repeats of 11 amino acids (Mattei et al., 1989). Antibodies raised against the recombinant polypeptide cross-reacted with a series of $P$. falciparum antigens, such as Pfl1-1 (Koenen et al., 1984; Scherf et al., 1988) and Pf155/RESA (Coppel et al., 1984; Perlmann et al., 1984). The common aspects shared by these antigens is the presence of repeats represented by the consensus-EE-XX-EE-, where $X$ is mostly a hydrophobic amino acid. The products of the Pfl 1-

This work has been supported by grants from M.E.S.R.S. France (Eureka N $\mathrm{N}^{\circ}$ 87W0043).
1 and Pf155/RESA genes were identified as respectively, polypeptides of apparent molecular weight lmegaDa (Petersen, et al., 1990) and $155 \mathrm{kDa}$ (Coppel et al., 1984; Perlman et al., 1984). The Pf332 gene product was difficult to identify due to the antibody cross-reactivites.

The cross-reactions were also observed with the human monoclonal antibody (33G2 (mAb $33 G 2$ ), which had been selected by its reactivity with the Pf155/RESA antigen (Udomsangpetch et al., 1986). This $\mathrm{mAb}$ is able to inhibit in vitro both the invasion of red blood cells by merozoites and the cytoadherence of infected erythrocytes on the melanoma cell line C32 assays (Udomsangpetch et al., 1986; Udomsangpetch et al., 1989a).

The Pf332, Pf11-1 and Pf155/RESA purified recombinant polypeptides, or synthetic peptides were analyzed by surface immunofluorescence of infected by red blood cells (IRBC), for their capacity to inhibit the mAb33G2 reactivity. Their ability to reduce the inhibition of the merozoite invasion of erythrocytes by mAb332G2 was also tested (Udomsangpetch et al., 1989a). The Pf332 recombinant polypeptide, or its synthetic peptides were the most efficient in inhibiting mAb332G2 in both as- 
says. These results suggested that the 332 antigen (Ag332) is the main target of the mAb33G2 and is of potential interest regarding protective immunity.

Recently, the epitope recognized by the mAb33G2 was identified as a linear sequence represented by five amino acids, VTEEL, where all residues, but the second $\mathrm{E}$, can be substituted by those with analogous chemical properties. This sequence, or the allowed substitutions, is frequently found in the Ag332, thus explaining its strong reactivity with the mAb33G2 (Ahlborg et al., 1991).

\section{CHARACTERIZATION OF THE Pf332 GENE}

In order to identify the Pf332 gene, we screened genomic and cDNA libraries using the G332 clone as a probe. Three overlapping genomic clones, G1, G9 and G90, of $2.9 \mathrm{~kb}$, $4.8 \mathrm{~kb}$ and $1.9 \mathrm{~kb}$, respectively, and a cDNA clone (C1) of $466 \mathrm{bp}$ were further characterized (Fig. 1). Digestion of the inserts of G1, G9 and G90 with the endonuclease MboIl revealed that they are composed exclusively of repeats. These data were confirmed by partial DNA sequence of the genomic clones and full sequence of the cDNA Cl insert. We have previously isolated a clone, Pf118, which also represent a fragment of the Pf332 gene (Kun et al., 1991) and taken together we have analyzed over $8 \mathrm{~kb}$ of Pf332 repeats.

The size of the Pf332 gene was estimated by Southern blot of $P$. falciparum DNA digested by mung bean nuclease in the presence of different concentrations of formamide (McCutchan et al., 1984). The Pf332 G1 probe hybridized with a unique fragment of about $20 \mathrm{~kb}$ consistent with the Northern blood analysis which revealed an asexual stage specific

i

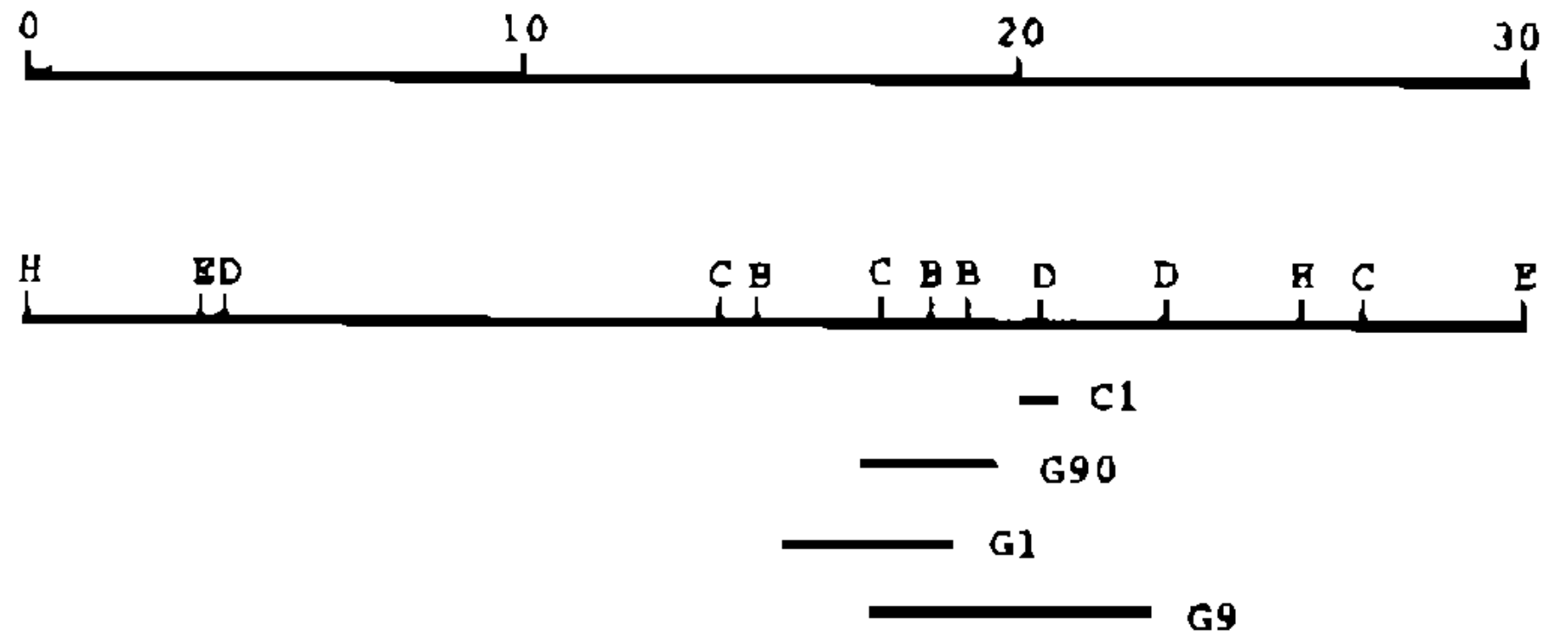

Fig. 1: restriction map of the Pf332 gene (Palo Alto) and schematic representation of the genomic clones G1, G9 and $G 90$ and the cDNA clone $C 1$. The restriction sits BamHI (B), ClaI (C), Dra I (D), EcoRI (E) and HindIll (H) are indicated. transcript larger that $10 \mathrm{~kb}$. In contrast, the Pfll. l gene hybridizes exclusively with mRNA from gametocytes (Scherf et al., manuscript in preparation). These data suggest that Pf332 encodes a protein of about $700 \mathrm{kDa}$ expressed during the asexual erythrocytic cycle of $P$. falciparum (Mattei \& Scherf, 1991).

Genomic DNA of six strains from different geographical regions (Palo Alto, Uganda; T9. 96. Thailand; FCBR, South America; 3D7, derived from NF54, Netherlands; Banjul, Gambia and 7G8, Brazil) were digested by AluI, which cuts frequently within the gene, followed by Southern blot analysis. The Pf332 gene is present in all strains investigated and shows an extreme restriction fragment length polymorphism (RFLP). The pattern observed with the Palo Alto strain remained unchanged during prolonged in vitro culture of the parasites. This suggests that the RFLP observed was not generated by random deletions, or by recombination during the mitotic divisions.

The Pf332 gene has been located in the subtclomeric region of the chromosome 11 by two-dimensional pulsc field gel elcctrophoresis (Fig. 2, Mattei \& Scherf, 1992). The chromosomes were separated in the first dimension and digested by ApaI, BgII, or SmaI. After migration in the second dimension, the restriction fragments were transferred and the same membrane was successively hybridized with the Pf332 G1, the subtelomeric Rep20 (Patarapotikul \& Langsley, 1988) and the telomeric (Ponzi et al., 1985) specific probes. The three probes hybridized with the same fragments of $245 \mathrm{~kb}$ and $190 \mathrm{~kb}$ generated by BgII and SmaI, respectively. It has been shown that the subtelomeric region of $P$. falciparum chromosomes is very unstable and it is a target of genetic recombination (Patarapotikul \&

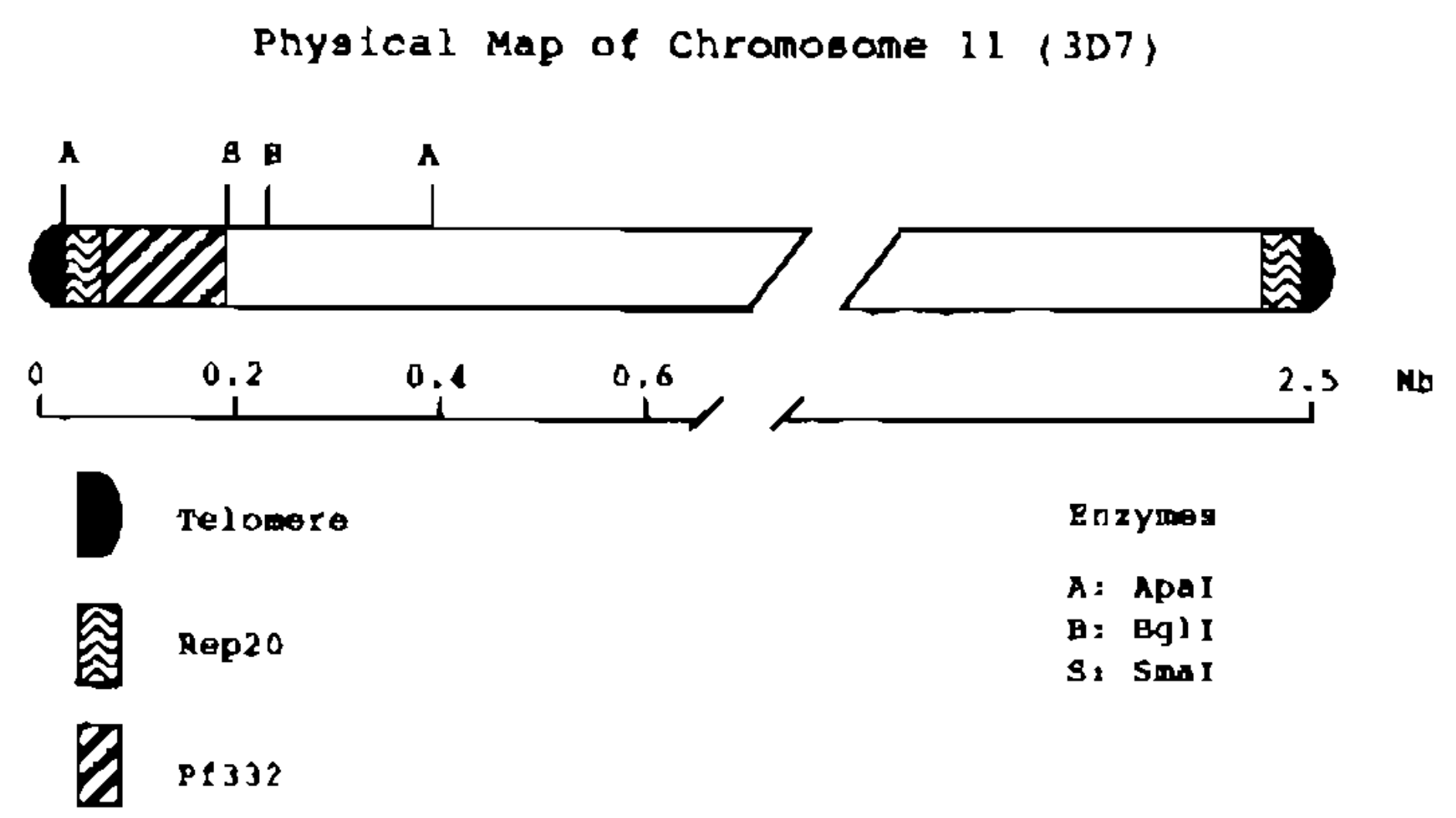

Fig. 2: partial map of chromosome 11 (3D7 strain). The positions of the telomeric ( $\bullet$ ), subtelomeric rep20 (e) and $\mathrm{Pf} 32$ gene (D) are shown. The restriction sites ApI (A), BgII (B) and Smal (S) are indicated. 
PfEB200 clone: DNR and anino acid deduced sequences

1 GGA TCC GTA ACT GAA GAA GTT GTA GGA GAR GAA ARA TTA GTT AGT GAA GAA ATA GTA ACG gly ger val thr glu glu val vol gly glu glu lys leu val ser glu glu lle val thr $61 / 21$

GAF GAA GGA TCT GTT GCT CAA GAA ATA GTA GAA GRA GAT GCA CCA GCT ACT GAR GAA ATT glu glu gly ser val ala gln glu llo ual glu glu asp ala pro ala thr glu glu lle $121 / 41$

GAT GAF ATA GAA TCA GTT RCT GAA GAR GTT GTC GAA GAR GAA GGA CCT GTT GAT GAR GRA asp glu ile glu ser val thr glu glu vol val glu glu glu gly pro val asp glu glu $181 / 61$

RTT GTA CAA GAR GAA GGT ACA GTT RCT GRA GAR ATA ATA CAA GGA GAA TCT AAR GTT GAA ile val gln glu glu gly thr val thr gluglu ilo ile gin gly glu oer lys val glu $241 / 81$

GAG GTC GTA GAA GAR CAA GGA TCT GAA AAT GAA GAA ATA TTC GTA GAA GAA GTA TCA GCT glu val val glu glu gln gly ser glu asn glu glu lio phe val glu glu val ser ala $301 / 101 \quad 331 / 111$

ICT CAA GAA ATA GTA CAA ART GAA TCA GGT ACC GAA GAA ATA TTG GAA AAR GTA TCA GCT ser gln glu ile val gln asn glu oer gly thr glu glu ile leu glu lyo val sor ala $361 / 121$

TCT CAA GAR ATA GTA CAA GAT GGA TCA GTT RCT GAA CAR ATA ATA GAR TTC ser gln glu ile wal glh asp gly ger val thr glu gln ile lle glu phe

Fig. 3: DNA and deduced amino acid sequences of EB200.
Langsley, 1988; Corcoran et al., 1988; Pologe \& Ravetch, 1988; Wellems et al., 1987). The Pf332 gene polymorphism could be due to its subtelomeric location. This region might represent a hot spot of recombinational events taking place at meiosis during the parasite development in the mosquito host (Vernick et al, 1988).

\section{CHARACTERIZATION OF THE Ag332}

In order to identify the Pf332 gene product, an insert of 411 bp generated by EcoRI-BamHI digestion of the Gl was cloned in the pGEX expression vector (Smith \& Johnson, 1988). This recombinant, named EB200, codes for 13 degenerated repeats of 10 , or 11 amino acids (Fig. 3). Anti-EB200 antibodies were raised and tested by their reactivity on Western blots, immunoprecipitation of parasite extracts and by immunofluorescence. On Western blots, the anti-EB200 serum recognizes a high molecular weight polypeptide migration in the $4 \%$ stacking SDS-polyacrylamide gel. The same result was obtained by immunoprecipitation of ${ }^{35} \mathrm{~S}$ methionine metabolically-labelled parasites (Mattei \& Scherf, 1992). The Ag332 migrates as a polypeptide of apparent molecular weight 2.5 megadalton as compared with the immunoprecipitation Pfl1-1 gene product. The discrepancy between the estimated and observed molecular weight values might be explained by post-translational modifications of the Ag332, like glycosylation, and/or anomalous binding of SDS due to the charged repeats.

The immunofluorescence reaction of airdried parasites with the EB200 antiserum shows a punctuated pattern on tropozoite and schizonte-infected red blood cells. The location of the Ag332 within the IRBC was better analyzed by immunofluorescence followed by visualization in a confocal microscope. The Ag332 is transported from the parasite to the membrane of the erythrocyte within large (about 0.5-1 um) vesicle-like structures. The antigen association with the membrane of the red blood cell was further supported by double-labelling with the anti-EB200 and anti-HRPI antibodies (Fig. 4). This latter antigen has been demonstrated to be located in the membrane of the IRBC under the knobs (Taylor et al., 1987). In addition, the immunofluorescence of living parasites shows that some epitopes of the Ag332 are exposed on the surface of monkey infected erythrocytes.

\section{CONCLUDING REMARKS}

We have cloned and characterized part of $P$. falciparum gene, named Pf332, expressed by asexual intra-erythrocytic parasites. The corresponding antigen is a megadalton protein which appears to be translocated within vesiclelike structures to the erythrocyte membrane. Furthermore, Ag332 was detected on the sur- 
a
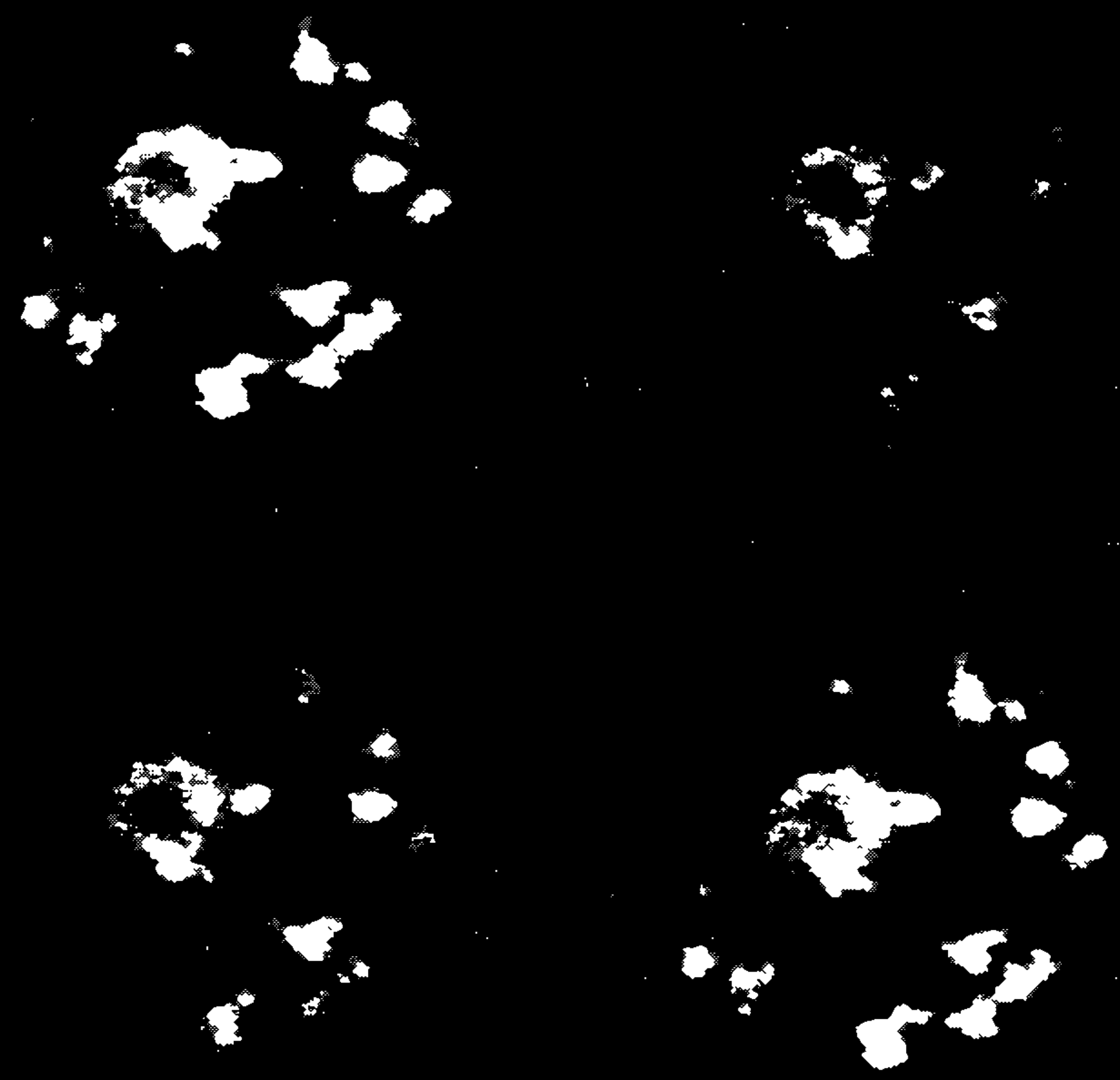

3

b
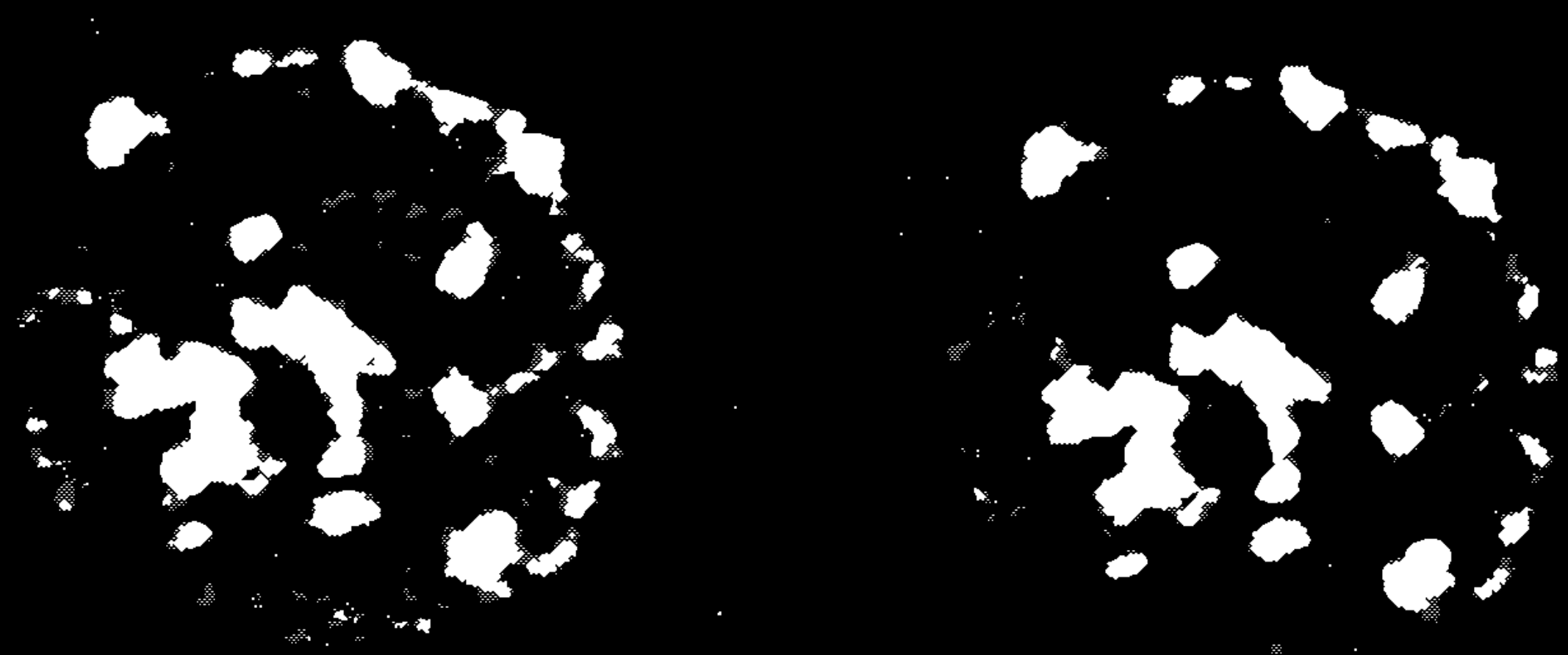

?

3
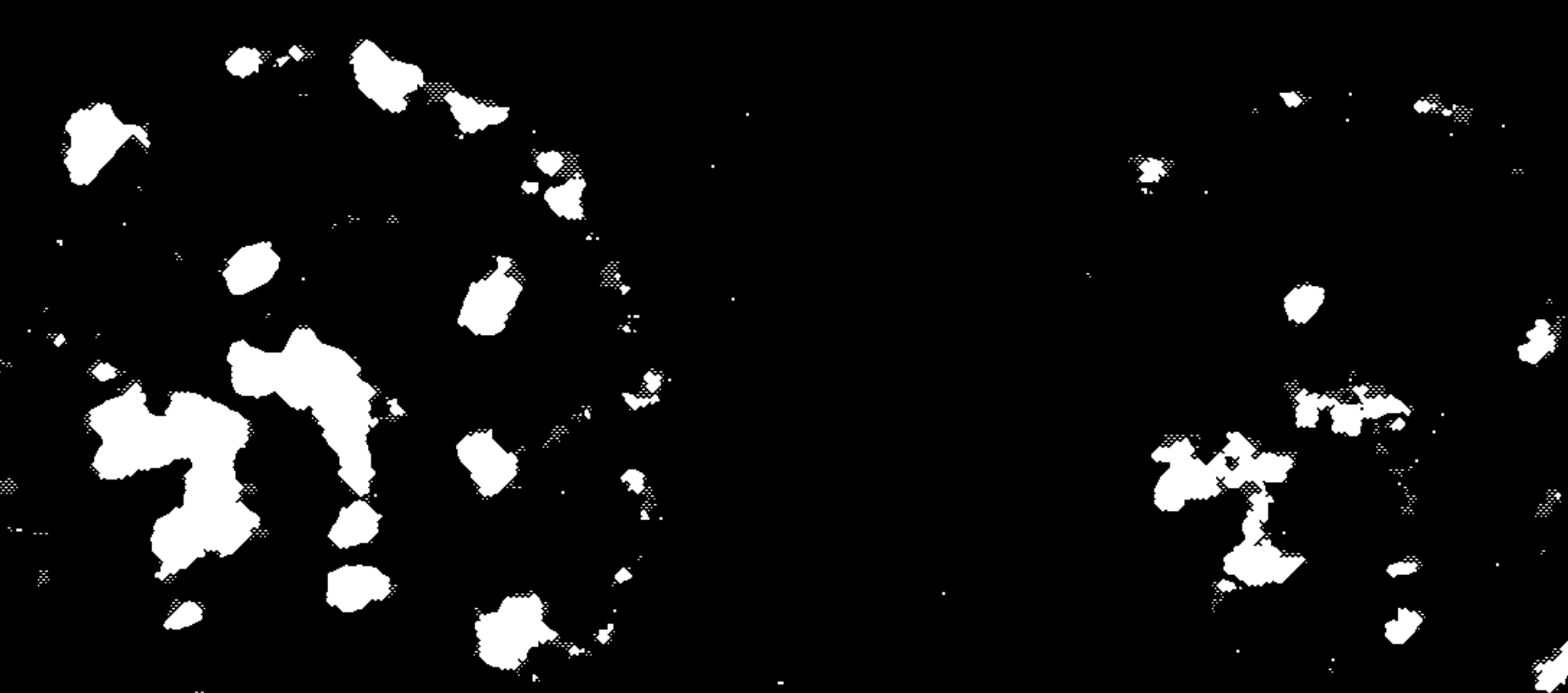

4

Yig. 4: confocal microscopy showing the indirect immunofluorescence pattern on of a Plasmodium falciparum infected red blood cell reacted with the (a): anti-E13200 serum and (b): double labelling with anti-EB200) and anti-HRPI sera. The pictures represent different plans of the same ccll $(1 \mu \mathrm{m} / \mathrm{plan})$. The upper right panels correspond to the superposed image of the other three panels. 
face of monkey erythrocytes infected with $P$. falciparum. suggesting some epitopes are expose. Finally, Ag332 strongly reacts with the human monoclonal antibody $33 \mathrm{G} 2$ that inhibits the cytoadherence of IRBC on melanoma cells and the invasion of $\mathrm{RBC}$ by the merozoites. These data taken together suggest that the Ag332 might be an important target of the host's protective immune response.

\section{ACKNOWLEDGEMENTS}

To Prof. L. Pereira da Silva for his support and helpful discussions and Dr G. Langsley for critical comments on the manuscript.

\section{REFERENCES}

AHLBORG, N.; BERZINS, K. \& PERLMANN, P., 1991. Definition of the epitope recognized by the Plasmodium falciparum-reactive human monoclonal antibody 33G2. Mol. Biochem. Parasitol., 46: 89-96.

BERENDT, A.R.; FERGUSON, D.J.P. \& NEWBOLD, C.I., 1990. Sequestration in Plasmodium falciparum malaria: Stick cells and sticky problems. Parasitol. Today, 6: 247-254.

COPPEL, R.L.; COWMAN, A.F.; ANDERS, F.R.; BIANCO, A.E.; SAINT, R.B.; LINGELBACH, K.R.; KEMP, D.J. \& BROWN, G.V., 1984. Immune sera recognize on erythrocytes a Plasmodium falciparum antigen composed of repeated amino acid sequences. Nature, 310: 789-792.

CORCORAN, L.M.; THOMPSON, J.K.; WALLIKER, D. \& KEMP, D.J., 1988. Homolgous recombination within subtelomeric repeat sequences generates chromosome size polymorphism in Plasmodium falciparum. Cell, 53: 807-813.

GROUX, H. \& GYSIN, J., 1990. Opsonization as an effector mechanism in human protection against asexual blood stage of Plasmodium falciparum: functional role of $\operatorname{IgG}$ subclasses. Res. Immunol., 141: 529-542.

GROUX, H.; PERRAUT, R.; GARRAUD, O.; POINGT, J.P. \& GYSIN, J., 1990. Functional characterization of the antibody-mediated protection against blood stages of Plasmodium falciparum in the monkey Saimiri sciureus. Eur. J. Immunol., 20: 2317-2323.

KOENEN. M.; SCHERF, A.; MERCEREAU, O.: LANGSLEY, G.; SIBILLI, L.; DUBOIS, P.; PEREIRA DA SILVA, L. \& MULLER-HILL, B., 1984. Human antisera detecl a Plasmodium falciparum genomic clone encoding a nonapeplide repeat. Nature, 311: 382-385.

KUN, J.; HESSELBACH, J; SCHREIBER, M.; SCHERF, A.: GYSIN, J.; MATTEI, D.; PEREIRA DA SILVA, L. \& MÜLLER-HILI, B., 1991. Cloning and expression of genomic DNA sequences coding for putative erythrocyte-associated antigens of Plasmodium falciparum. Res. Immunol, 142: 199. 210.

MATTEI, D.; BERZINS, K.; WAHLGREN, M.; UDOMSANGPETCH, R.; PERLMANN, P.; GRIES-
SER, H.W.; SCHERF, A.; MULLER-HILL, B.; BONNEFOY, S.; GUILLOTTE, M.; LANGSLEY, G.; PEREIRA DA SILVA, L. \& MERCEREAUPUIJALON, O., 1989. Cross-reactive antigenic determinants present on different Plasmodium falcipanum blood stage antigens. Parasite Immunol., Jl: $15-30$.

MATTE1, D. \& SCHERF, A., 1992. The PF332 gene codes for a giant protein that is translocated from the parasite to the membrane of infected erythrocytes. Gene 110: 71-79.

McCUTCHAN, T.F.; HANSE, J.L.; DAME, J.B. \& MULLINS, J.A., 1984. Mung bean cleaves Plasmodium falciparum genomic DNA at sites before and after genes. Science, 225: 625-628.

PATARAPOTIKUL, J. \& LANGSLEY, G., 1988. Chromosome size polymorphism in Plasmodium falciparum can involve deletions of the subtelomeric pPFrep20 sequence. Nucl. Acids Res., 16: 4331-4340.

PERLMANN, H.; BERZINS, K.; WAHIGREN, M.; CALRSSON, J.; BJÔRKMAN, A.; PATARROYO, M.E. \& PERLMANN, P., 1984. Antibodies in malarial sera to parasite antigens in the membrane of erythrocytes infected with early asexual stages of Plasmodium falcipanum. J. Exp. Med., 159: 16861704.

PETERSEN, C.; NELSON, R.; LEECH, J.; JENSEN, J.; WOLLISH, W. \& SCHERF, A., 1990. The gene product of the Plasmodium falciparum 11.1 locus is a protein larger than one megadalton. Mol. Biochem. Parasitol., 42: 189-196.

POLOGE, I.G. \& RAVETCH, J.V., 1988. Large delections results from breakage and healing of Plasmodium falcipanum chromosome. Cell, 55: 869-874.

PONZI, M.: PACE, T.; DORE, E. \& FRONTALI, C., 1985. Identification of a telomeric DNA sequence in Plasmodium berghei. EMBO J., 4: 2991-2995.

SCHERF, A.; HILBICH, C.; SIEG, K.; MATTEl, D.; MERCEREAU-PUIJALON, O. \& MULLER-HILL, B., 1988. The 11-1 gene of Plasmodium falciparum codes for distinct fast evolving repeats. $E M B O \mathrm{~J} ., 7$; $1129-1137$.

SMITH, D.B. \& JOHNSON, K.S., 1988. Single-step purification of polypeptides expressed in Escherichia coli as fusion proteins with glutahione S-transferase. Gene, 29: 31-40.

TAYLOR, I.W.; PARRA, M.; CHAPMANN, G.B.; STEARNS, M.E.; RENER, J.; AIKAWA, M.; UNI, S.; ALEY, S.B.; PANTON, L.J. \& HOWARD, R.J., 1987. Localization of Plasmodium falciparum histidine rich protein I in the erythrocyte skeleton under knobs. Mol. Biochem. Parasitol., 25: 165-174.

UIDOMSANGPETCH, R.; LUNDGREN, K.; BERZINS, K.; WAHLIN, B.; PERLMANN, H.; TROYEBLOMBERG, M.; CARLSSON, J.; WAHLGREEN, M.; PERLMANN, P. \& BJÔRKMAN, A., 1986. Human monoclonal antibodies toPf155, a mojor antigen of malaria parasite Plasmodium falciparum. Science, 231: 57-59.

UDOMSANGPETCH, R.; AIKAWA. M.; BERZINS, K.; WAHLGREN, M. \& PERLMANN, P., 1989a. Cytoadherence of knobles Plasmodium falciparuminfected erythrocytes and its inhibition by human monoclonal antibody. Nature, 338: 763-765.

UDOMSANGPETCH, R; CARLSSON, J.; WAHLIN, B.; HOLMQUIST, G.; OZAKI, L.S.; SCHERF, A.; 
MATTEI, D.; MERCEREAU-PUIJALON, O.; UNI. S.; AIKAWA, M.; BERZINS, K. \& PERLMANN, P., 1989b. Reactivity of the human monoclonal antibody 33G2 with repeat sequences of three distinct Plasmodium falciparum antigens. J. Immunol., 142: 3620-3626.

VERNICK, K.D.; WALLIKER, D. \& McCUTCHAN, T.F., 1988. Genetic hypervariability of telomere-related sequences is associated with meiosis in Plasmodium falciparum. Nucl. Acids Res., 16: 6973-6985.
WAHLGREN, M., 1986. Antigens and antibodies involved in humoral immunity to Plasmodium falciparum. The. sis, Karolinska Institutet, Stockholm, Sweden.

WELLEMS, T.E.; WALLIKER, D.; SMITH, C.L.; ROSARIO, V.E.; MALOY, W.L.; HOWARD, R.J.; CARTER, R. \& McCUTCHAN, T.F., 1987. A histidine-rich protein gene marks a linkage group favoured strongly in a genetic cross of Plasmodium falciparum. Cell. 49: 633-642. 